Sains Malaysiana 50(6)(2021): 1621-1638

http://doi.org/10.17576/jsm-2021-5006-10

\title{
Screening of Rice Varieties Based on Remodeling of Root Architecture Linked to Enhanced Phosphorus Transporters and Ethylene Signaling for Better Phosphorous Acquisition under Limiting Conditions
}

(Saringan Varieti Padi berdasarkan Pembentukan Semula Arkitektur Akar berkait dengan Pengangkut Fosforus dan Pemberian Isyarat Etilena untuk Pemerolehan Fosforus yang Lebih Baik dalam Keadaan Terhad)

\author{
Alveena Zulfiqar, Beenish Jehan Azhar, Aroosa Zeb, Asyia Zeenat, Sitwat Aman, Scott a \\ HECKERTHORN \& SAMINA N SHAKEEL*
}

\begin{abstract}
Root architectural modifications in response to altered nutrient level can be used as selection marker for better adapted rice varieties. In this study, we screened six local rice varieties commonly grown in Pakistan, using their unique root architecture and several molecular markers to identify best adapted local variety under phosphorus limiting conditions. Our data showed that rice variety with significant changes in its three-dimensional root architecture system (RSA) and enhanced expression of phosphorus transporters (OSPT2, OSPT4 and OSPT6) is the best variety to handle stress as compared to other varieties. Along with development of screening strategy/method, our data provided evidence that phosphorus starvation leads to upregulation of stress hormone ethylene, which regulates root elongation and root hair development therefore facilitating root architecture modification. We then further checked, how to mitigate or enhance phosphorus starvation responses by application of hormones exogenously, our results showed that ethylene application/ treatment enhances phosphorus starvation responses, whereas cytokinin on the other hand reverses deficiency effects which implicates hormonal cross talk is key to modulate P-deficiency responses in rice. This study provides an easy and quick method of analysis of root architecture as physiological marker for rice screening and improve crop yield by selecting best adapted variety for P deficient soils. In future, detail study for understanding phytohormone mediated transcriptomic changes in response to nutrient deficiency and in correlation with physiological response will help to select better adapted varieties that will eventually result in increase of rice yield.
\end{abstract}

Keywords: Cytokinin; ethylene biosynthesis; nutritional stress; phosphate transporters; root architecture

\section{ABSTRAK}

Pengubahsuaian arkitektur akar sebagai tindak balas terhadap perubahan tahap nutrien dapat digunakan sebagai penanda pilihan bagi varieti padi yang lebih sesuai. Dalam kajian ini, kami meneliti enam varieti padi tempatan yang biasanya ditanam di Pakistan dengan menggunakan arkitektur akarnya yang unik dan beberapa penanda molekul untuk mengenal pasti varieti tempatan yang paling sesuai dalam keadaan yang membatasi fosforus. Data kami menunjukkan bahawa varieti padi dengan perubahan ketara dalam sistem arkitektur akar tiga dimensi (RSA) dan peningkatan ekspresi pengangkut fosforus (OSPT2, OSPT4 dan OSPT6) adalah varieti yang terbaik untuk menangani tekanan berbanding dengan varieti lain. Seiring dengan perkembangan strategi/kaedah penyaringan, data kami memberikan bukti bahawa kebuluran fosforus membawa kepada peningkatan etilena hormon tekanan yang mengatur pemanjangan akar dan pertumbuhan rambut akar sehingga memudahkan pengubahsuaian arkitektur akar. Kami kemudiannya mengkaji lebih lanjut tentang bagaimana mengurangkan atau meningkatkan tindak balas kebuluran fosforus dengan penggunaan hormon eksogen. Keputusan kami menunjukkan bahawa aplikasi/rawatan etilena meningkatkan tindak balas kebuluran fosforus, sedangkan sitokinin sebaliknya membalikkan kesan kekurangan yang menyiratkan perbincangan silang hormonal adalah kunci untuk memodulasi tindak balas kekurangan P dalam padi. Kajian ini memberikan kaedah analisis seni arkitektur yang mudah dan cepat sebagai penanda fisiologi untuk penyaringan padi dan meningkatkan hasil tanaman dengan memilih varieti yang paling sesuai bagi tanah yang kekurangan P. Pada masa depan, kajian terperinci untuk memahami perubahan transkriptom yang dimediasi fitohormon sebagai tindak balas terhadap kekurangan nutrien dan berkorelasi dengan tindak balas fisiologi akan membantu untuk memilih varieti yang lebih baik yang akhirnya akan menghasilkan peningkatan hasil padi.

Kata kunci: Arkitektur akar; biosintesis etilena; pengangkut fosforus; sitokinin; tekanan pemakanan 


\section{INTRODUCTION}

According to recent survey by United Nations, it is expected that by 2024 , world population will reach around 8 billion (http://esa.un.org/unpd/wpp/Publications/). Due to an exponential increase in world population, it is crucial to take necessary measures to increase food production to meet the growing requirement. Along with a rapid increase in world population, the other major threat is environmental changes limiting crop production (Lobell \& Gourdji 2012). Researchers throughout the world are studying different methods to enhance food production and limit adverse impact on the environment, for example recently Hassan et al. (2020) reported laser application mediated enhancement in plant growth characteristics.

In this study, we devised a simple method to identify better adapted rice varieties to sustain in phosphorus limited environment. Rice is an important staple food, as $60 \%$ of the world population consumes rice. Annual rice production is around 480 million metric tons, almost $50 \%$ of the rice grown is consumed by China and India alone. Rice accounts for $50 \%$ of nutrient supply of millions of poor people of Asia, thus, rice is considered as key nutrient source in Asian countries. Similarly to Asian countries, it is also a staple food of Latin America and Africa. Rice is an important food commodity and is being traded worldwide (Muthayya et al. 2014). With the boost in population, the rice yield is not increasing at the similar pace. Therefore, it is need of the hour to enhance rice production worldwide to meet up the demand. Mostly the characteristics responsible for good yield of rice are heritable (Rafii et al. 2014), therefore, identification of better adapted varieties will benefit in longer run to meet the demand of high yield.

Different abiotic and biotic stress leads to yield reduction of rice every year, among them the most important factor determining rice yield is availability of phosphorus (Chithrameenal et al. 2018). Phosphorus (P) deficiency is one of the major factors limiting crop yield globally. To cope-up phosphorous starvation, several plants develops unique species and variety specific morphological and physiological responses to sustain in nutrient deficient environment. Active uptake of phosphorus from soil by plants is very important to maintain concentration gradient. As phosphorus plays essential role in plant growth and development, plants maintain phosphorus homeostasis by developing series of adaptive responses to acquire external P (Poirier \& Bucher 2004). Mostly, natural ecosystem has low available phosphorus, which in turn results in stunted plant growth. Plants as a result have evolved mechanisms to cope-up phosphorus deficiency by attaining multiple morphological adaptations as well as biochemical and symbiotic strategies that results in upregulation of the acquisition of Phosphorus from the environment and improved efficiency of phosphorus utilization (Karthikeyan 2002). The most prominent adaptation response as a result of phosphorus deficiency is change in root morphology, which includes cluster root formation and increase in lateral root density that help plants to explore soil for phosphorus uptake (Nadira et al. 2016). Besides change in root architecture, plants roots release organic acids and acid phosphatases that results in rise of available phosphorus for uptake from the immediate vicinity by enhanced root architecture (Péret et al. 2014). Different plant species and even varieties respond differently to phosphorus deficient conditions for example in Arabidopsis and beans phosphorus starvation results in primary root elongation and an increase in number of lateral roots with secondary root branching (Zhang et al. 2014). However, many plant species with an increase in root hairs density and length has been observed to reduce $\mathrm{P}$ deficiency, which increases root surface area to enhance $P$ uptake (Campos et al. 2018).

Therefore, phosphate availability is the limiting factor for optimal plant growth, several phosphate fertilizers are commercially available but phosphorus being non-renewable mineral source and can easily leach out from soil (Elser 2012). Chemical fertilizers results in greenhouse gas emission that in turn result in environmental hazards and global warming (Harun et al. 2020), therefore, an alternative option to overcome the use of chemical based fertilizers is to identify the best adapted variety that can sustain the abiotic stress better. For minimizing rate of climate change, it is crucial to move towards sustainable development i.e. to meet today's requirements without compromising needs of future generation (Aziz \& Hanafiah 2020). Thus, by selecting more adaptable varieties, we can minimize the use of chemical fertilizers and eventually climate change. Different traits of plants can be used to evaluate growth rate and eventually identifying better variety amongst others (Che Mat et al. 2015).

Recently many genes from different plant species have been identified as proton-coupled $\mathrm{P}$ transporters $(\mathrm{H}+/ \mathrm{H} 2 \mathrm{PO} 4 \pm$ symporters $)$, these transporters were further subdivided into high and low affinity transporters. First high affinity phosphorus transporter PHO84 was identified in yeast (Saccharomyces cerevisiae) (Teng et al. 2017). Later, many phosphorus transporters were isolated and characterized from other plant species for example 19 genes encoding phosphorus transporters were identified in Arabidopsis, similarly 26 phosphorus transporter genes in 
rice were characterized (Młodzińska \& Zboińska 2016). In dicot and monocot plants all phosphorus transporters are subdivided into four subfamilies i.e. PHT1 to PHT4 on the basis of similarity in structural and subcellular localization. Mostly phosphorus transporters are localized at plasma membrane, chloroplast, mitochondria, and Golgi apparatus, respectively. Increase in the number of high affinity phosphorus transporter is another evolutionary adaptation for uptake of phosphorus from the phosphorus deficient rhizosphere for the survival of plant (Hasan et al. 2016). Uptake of phosphorous heavily relies upon PHT1 transporter proteins and its levels controlled by complex set of regulations ( $\mathrm{Gu}$ et al. 2016).

Phytohormones are small molecules produced in very low concentrations and act as chemical messengers to communicate between cells and regulate several cell processes (Voß et al. 2014). Although plant responses to nutrient deficiency depends on several factors, phytohormones are considered to be the most important molecules produced endogenously for modulations of physiological and molecular responses to such environmental stress (Fahad et al. 2015). Ethylene, one of the major phytohormone, is considered as a major modulator in response to environmental stresses (Jackson 2008). It is also known as an 'aging hormone' as it is involved in several developmental processes e.g. ripening, abscission, and senescence. Genetic analysis on Arabidopsis model plant identified certain key elements that act to mediate ethylene responses (Stepanova \& Alonso 2009). Ethylene regulates root elongation, lateral root proliferation and also known to determine the fate of cell during production of root hairs. Ethylene is also known as stress hormone, as different abiotic and biotic stresses lead to upregulation of ethylene signaling. It has been observed that ethylene biosynthesis alters by $\mathrm{P}$ deficiency. Some reports showed that ethylene production increases under P deficiency as in roots of Phaseolus vulgaris, Madicago falcate and white Lupines albus (Song \& Liu 2015). In contrast, ethylene production decreased in tomato and maize under P deficiency (Kim et al. 2008). In previous studies, quantitative reverse transcription PCR (RT-qPCR) showed that expression levels of ACS family genes were enhanced in Arabidopsis seedlings grown in $\mathrm{P}$ deficient medium. The enhanced ethylene biosynthetic gene levels showed causal relationship of ethylene and $\mathrm{P}$ levels in soil (Kang et al. 2014).

In the present study, we investigated effect of phosphorous deficiency at physiological and molecular levels, to identify better adapted variety from selected varieties commonly grown in Pakistan. Therefore, we examined the root architectural modifications under $\mathrm{P}$ deficient conditions to develop a simple method for identification of better adapted variety. We further analyzed expression of phosphorus transporter and ethylene biosynthesis/signaling genes in two selected varieties to corelate our expression data with physiological data. An alternative option to modulate physiological and molecular responses is by application of plant hormones. In the current study, we also investigated phosphorus deficiency responses under exogenous cytokinin and ethylene treatment.

\section{MATERIALS AND METHODS}

\section{PLANT MATERIAL AND GROWTH CONDITIONS}

Six commonly grown rice cultivars (Fakhar-e-Malakand, Shadab, IR-6, Super Kernel, Super Basmati and Muskaan) of Pakistan and a Japonica rice $c v$. Kitaake (Oryza sative) variety were analyzed in this study to check the effect of phosphorous starvation on root architecture and ethylene signaling. Fourteen days old seedlings were grown hydroponically at three varying phosphorus concentration i.e. $\mathrm{P}_{\mathrm{N}}$ : normal concentration of $\mathrm{P}(2 \mathrm{mM}), \mathrm{P}_{1 / 2}$ : Half or $\mathrm{P}$ deficient condition $(1 \mathrm{mM})$, and $\mathrm{P}_{0}$ : Zero or no $\mathrm{P}$ concentration. The Hoagland solution contained $\mathrm{KH}_{2} \mathrm{PO}_{4}$ (1 mM), $\mathrm{MgSO}_{4}(1 \mathrm{M}), \mathrm{K}_{2} \mathrm{HPO}_{4}(1 \mathrm{mM}), \mathrm{CaCl}_{2}(1 \mathrm{M})$, $\mathrm{H}_{3} \mathrm{BO}_{3}(40 \mathrm{mM}), \mathrm{Na}_{2} \mathrm{MoO}_{4}(1 \mathrm{mM}), \mathrm{Fe}-\mathrm{DTPA} / \mathrm{Fe}-\mathrm{HEDTA}$ (71 mM), $\mathrm{CuSO}_{4}(20 \mathrm{mM}), \mathrm{MnCl}_{2}(60 \mathrm{mM}), \mathrm{Ca}\left(\mathrm{NO}_{3}\right)_{2}(6$ $\mathrm{mM}), \mathrm{ZnSO}_{4}(20 \mathrm{mM})$ and $\mathrm{KNO}_{3}(1 \mathrm{mM})$. The Hoagland solution was renewed after every 3 rd day. The experiment was conducted in the growth chamber provided with 12 $\mathrm{h}$ light of $500 \mu \mathrm{mol} \mathrm{m} \mathrm{s}^{-2} \mathrm{~s}^{-1}$ intensity and $12 \mathrm{~h}$ dark cycle, with $\sim 60 \%$ humidity and $30{ }^{\circ} \mathrm{C}$ temperature. On 14 th day, seedlings were scanned to check the changes in root architecture under different phosphorous conditions. Roots architecture was analyzed with General Image Analysis (GIA) software (Galkovskyi et al. 2012). For molecular analysis, tissues were preserved in liquid nitrogen. On the other hand, to check effect of cytokinin and ethylene when exogenously applied, Japonica rice variety was grown under full phosphorus and zero phosphorus with and without $1 \mu \mathrm{M}$ BAP (6-benzylaminopurine) and $1 \mu \mathrm{M}$ ACC (ethylene precursor).

\section{MEASUREMENT OF PHOTOSYNTHETIC ACTIVITY}

To analyse phosphorus starvation effect on photosynthesis, chlorophyll content was measured using the pocket Hansatech Pocket PEA chlorophyll 
fluorimeter. To measure $\mathrm{Fv} / \mathrm{Fm}$ ratios and photosynthetic index (P), DAI fluorimeter was used according to the instructions provided by the manufacturers $(\mathrm{Xu}$ et al. 2007).

\section{MICROSCOPIC ANALYSIS OF ROOT APICAL MERISTEM}

Effect of P deficiency was examined on root apical meristem of selected rice variety seedlings. Primary root tips were microscopically analyzed to count cell number at root apical meristem (RAM). As RAM is further divided into three major zones i.e. stem cell niche, division zone and the zone of elongation. Root apical meristems (RAM) were analyzed by taking root tips and soaking in chloral hydrate solution (chloral hydrate, water and glycerol in 8 : 3: 1 ratio) for $20 \mathrm{~min}$. Root cortical layer cells were counted from quiescent center until size of cell changes in a line by using (Olympus, CX41).

\section{PRIMER DESIGNING}

To design the real time PCR primers, we first retrieved sequences of target and housekeeping genes from Gene bank of NCBI. Primers for all genes were designed by using Oligo Analyzer Tool of Integrated DNA technologies (IDT). Table 1 shows list of genes with sequences of primers designed.

\section{QUANTITATIVE (QRT) PCR AMPLIFICATION}

For transcriptional analysis, root tissue samples were collected and stored in liquid nitrogen. Trizole reagent (Cat. No 15596026; Ambion Life Technologies, USA) was used to extract RNA according to manufacturer's protocol. For DNase treatment, RNAse-free kit (Cat No. EN0521, Fermantas, USA) was used according to provided protocol. RNA(2ug) was used for cDNA preparation using Revert aid first strand cDNA synthesis kit (Cat No. K1622, Fermentas, USA) according to manufacturer's instruction. To analyze transcript levels, gene specific primers of phosphorous transporters (OsPT2, OsPT4 and OsPT6) and ethylene biosynthesis/signaling genes (OsACS1, OsACO, OsCTR1, OsEIN2) were designed using Integrated DNA technologies (IDT). Beta actin was used as an internal control gene for expression analysis. Table 1 shows primer sequences used for quantitative analysis. Maxima Cyber green/ROX PCR master mix (Cat No. K0221; Thermoscientific, USA) was used for real-time PCR with two technical replicates of each cDNA sample.

\section{PHYLOGENETIC ANALYSIS AND PROTEIN-PROTEIN} INTERACTION via STRING

To perform hierarchal study on phosphorus transporters we selected cluster I, all phosphorus-transporters included in cluster I are located in plasma membrane. To construct phylogenetic tree, we retrieved protein sequences of respective transporters form NCBI and then used an online web program phylogeny.fr to construct the phylogenetic tree. STRING protein network prediction database was used to construct protein interactions with OsPT2, OsPT4 and OsPT6.

\section{STATISTICAL ANALYSIS}

To statistically compare results of root morphological parameters, chlorophyll content, Fv/Fm ratio and RAM size of rice varieties grown in three different $\mathrm{P}$ conditions i.e. $\mathrm{P}_{\mathrm{N}}, \mathrm{P}_{1 / 2}$ and $\mathrm{P}_{0}$, one-way analysis of variance (ANOVA) followed by Holm-Bonferroni test at $\mathrm{p}<0.05$ significance level was done to measure differences between treatments within genotypes. Three biological replicates were used in each case.

\section{RESULTS AND DISCUSSION}

Phosphorus being macro nutrient is indispensable for plant growth and crop yield, different plant species and even different varieties of same species absorb and utilize phosphorus variably (Abbas et al. 2018; Akhtar et al. 2016; Aziz et al. 2014; Fageria et al. 2011; Irfan et al. 2017). The identification of rice variety that can respond to phosphorus starvation by inducing root architecture modifications and upregulation of phosphorus transporters more efficiently is a promising strategy to increase phosphorus absorption and crop yield. In this study, we hypothesized that different varieties respond to phosphorus differently and varieties can be screened on the basis of root architectural modification that can be linked to transcriptomic markers.

\section{ROOT ARCHITECTURE MODIFIES IN RESPONSE TO P AVAILABILITY}

To check the effect of phosphorous deficiency on root architecture modification, control seedlings were compared with phosphorous deficient seedlings after 14 days of growth. Primary root inhibition was observed in all six varieties but Fakhar-e-Malakand showed most pronounced effect on primary root inhibition as compared to other verities. Similarly, Fakhar-e-Malakand showed 
enhanced average root diameter, maximum number of roots and network area as compared to other varieties studied at phosphorus deficient condition (Figure 1).

Limited phosphorus is one of the major constrains for crop productivity in natural ecosystem. For survival in phosphorus limited environment, plants undergo several morphological and genetic changes (Raghothama 2000). Proper development of roots plays key role in plant growth by regulating water and nutrients uptake. They provide lifelong biological interaction between plant and microbiota either by facilitating the plant or assisting the chemical defenses underneath (Galkovskyi et al. 2012). For regulating phosphorus homeostasis, plants undergo different root architectural responses to maximize the phosphorus acquisition from soil. Therefore, root architecture modification is an important aspect to enhance phosphorus absorption (White et al. 2013). Such morphological, physiological, and biochemical alterations result in plant adaptation to phosphorus deficient environment and help to sustain nutrient deficiency. Although phosphorous influenced overall plant growth but it has an obvious effect on plant roots. Plant's ability to overcome P-deficient conditions varies in between different plant genotypes (López-Arredondo et al. 2014). In the current study, we presented an easy screening method to identify best adapted variety by analyzing effect of phosphorus deficiency in remodeling of root architecture system. Our results were in concomitant with other studies that showed lateral root development, primary root inhibition, an increase in root hair development and cluster root formation in response to phosphorous deficiency in rice. All these physiological and morphological adaptations assists plant to acquire $P$ from soil (Zeenat et al. 2018). Similar type of adaptations were reported in response to phosphorous deficiency in other cultivated plants including common bean (Phaseolus vulgaris), maize (Zea maize), tomato (Solanum lycopersicum), white Lupin (Lupinus albus) and Brassica nigra (Plaxton \& Tran 2011). Therefore, current study helps to understand rice varietal response towards P-deficient condition, on the basis of our data we conclude that Fakahar-e-Malakand is the better adapted variety as it showed maximum root modifications in P-deficient conditions, which helps the seedlings to explore adjacent rhizosphere to acquire more phosphorus. Thus, this variety is suitable to grow in soil with limited P-supply as it has ability to maximally modify its root architecture. On contrary to the best variety, we identified weak response variety i.e. showing minimal changes in root architecture. Such varieties if grown in areas with limited P-supply will get stressed and will not survive or give good yield.
REDUCED PHOTOSYNTHETIC ACTIVITY LINKED TO LOW P AVAILABILITY

To determine the effect of phosphorus starvation on plant's photosynthetic activity, we measured chlorophyll content and $\mathrm{Fv} / \mathrm{Fm}$ ratio of all rice varieties at different experimental conditions. The maximum efficiency of photosystem II $(\mathrm{Fv} / \mathrm{Fm})$ was decreased in leaves of $\mathrm{P}$ deficient plants of selected varieties as compared with control $\left(\mathrm{P}_{\mathrm{N}}\right)$ plants. Decrease in chlorophyll content and $\mathrm{Fv} / \mathrm{Fm}$ ratio indicates that phosphorus starvation induces negative effect on plant productivity by effecting photosynthetic ability of plant. Figure 2 shows chlorophyll content and $\mathrm{Fv} / \mathrm{Fm}$ ration of all six varieties at normal phosphorus $\left(\mathrm{P}_{\mathrm{N}}\right)$, phosphorus deficient $\left(\mathrm{P}_{1 / 2}\right)$, and phosphorus starved $\left(\mathrm{P}_{0}\right)$. Chlorophyll content decreased with decreasing phosphorus concentration. Similarly, Fv/Fm ratio was also compromised in seedlings grown at lower than optimum phosphorus concentration, indicating phosphorus starvation negatively influence plant productivity by effecting photosynthetic ability. Our finding further validates that phosphorus deficiency hampers ATP synthase activity thus resulting in reduction of ATP synthesis and $\mathrm{CO}_{2}$ fixation in plants therefore reducing overall photosynthetic activity of plants (Carstensen et al. 2018).

\section{COMPROMISED ROOT APICAL MERISTEMATIC ACTIVITY MEDIATED BY P- DEFICIENCY}

Cortex cells were counted to determine the RAM size starting from the quiescent center to the first elongated cell entering the elongation zone using microscopy of fourteen days old rice seedlings of six Pakistani varieties hydroponically grown (Figure 3(a)). Number of RAM cells decreased under $\mathrm{P}$ deficient conditions as compared with control plant seedlings. As root elongation occurs due to flux of newly formed cell from division zone to elongation zone in root apical meristem. Phosphorous starvation reduces the elongation of root by decreasing the rate of cell division hence reducing the cell number in elongation zone. Figure 3(b) shows number of cells decreased significantly in all six varieties studied. Our results were in concomitant with previous findings that primary root inhibition correlates with reduced cell differentiation and cell proliferation in the elongation zone (Svistoonoff et al. 2007). Number of cells in meristematic and elongation zone decreases in $\mathrm{P}$ deficient plant roots as compared with roots grown under normal $\left(\mathrm{P}_{\mathrm{N}}\right)$ phosphorous concentration (Ma et al. 2003). As reported earlier, ethylene hormone negatively regulate primary 
root growth by affecting cell elongation in root apical meristem (Swarup et al. 2007). Our data also supports that P-deficiency switches on ethylene signaling that in turn negatively regulates RAM size and primary root elongation.

\section{PHOSPHOROUS TRANSPORTERS (OSPTS) UP- REGULATION TO ENHANCE P-ACQUISITION}

In present study, we examined transcript levels of phosphorous transporters (OsPT2, OsPT4 and OsPT6) in roots of Fakhar-e-Malakand and Shadab variety under different phosphorous concentrations. Expression levels of the transporter genes OsPT2, OsPT4 and OsPT6 increases significantly under phosphorous starved (P0) condition in Fakhar-e-Malkand whereas opposite effect was observed in Shadab variety, it also showed weak morphological responses due to phosphorus starvation. Phosphorous uptake is carried out by phosphorous transporters (PTs or PHTs) which are special protein carriers. In Oryza sativa PHT1 family members usually consist of 508582 amino acids with molecular weight approximately $60 \mathrm{kDa}$ (Zeenat et al. 2018). Phosphorous acquisition and homeostasis majorly depends on phosphorous transporters (PTs) grouped into five families i.e. PHT1, PHT2, PHT3, PHT4, and PHT5 (Liu et al. 2016). Among these families, PHT1 was studied primarily and it consist of 13 members OsPT1-OsPT13 (Goff et al. 2002). Phosphorous transporters (OsPT1. OsPT2, OsPT4, OsPT6, and OsPT8) are directly involved in uptake of P (Ai et al. 2009). In previous studies, it is reported that most of PHT1 group members OsPT1, OsPT2, OsPT4, OsPT6, and OsPT8 involved in direct uptake of $\mathrm{P}$ from soil (Zhang et al. 2015). In similar study of rice, OsPT2 gene expression level increases in Low P conditions (Dai et al. 2012). The increased transcript level of OsPTs genes and protein under phosphorous deficiency provided the evidence of transcriptional regulation of transport and acquisition of phosphorous (Smith et al. 2000). Thus, molecular and physiological data support that Fakhare-Malakand variety and has the ability to cope up with phosphorus deficiency by modifying root architecture and also upregulating expression of phosphorus transporters enhance P-acquisition, whereas Shadab variety not only weakly responded in root morphological alterations but also had a weak transcriptional response to low phosphorus (Figure 4). Therefore, it validates that variety can be selected on basis of their root architectural response to P-starvation.

\section{EVOLUTIONARY ANALYSIS AND STRING NETWORK} ANALYSIS

All phosphorus transporters of cluster I are predicted to locate in plasma membrane, as discussed before, cluster I is involved in direct uptake of phosphorus we constructed phylogenetic tree to see evolutionary relationship amongst them. Protein sequences of OsPT1,2,3,4,5,6,7,8,9, $10,11,12,13$ were retrieved from NCBI. Proteins clustered together on the basis of highest similarity (Figure 5(a)). We further constructed STRING network of OsPT2, OsPT4, and OsPT6 to predict protein-protein association (Figure $5(\mathrm{~b})$ ). Table 2 gives list of interacting proteins with their functions, we found a couple of SPX proteins interaction with phosphorus transporters, $\mathrm{N}$-terminal SPX domain is a common feature of many signal transducing proteins and are key players in maintain P-homeostasis in plants (Liu et al. 2010). N-terminal SPX domain is a common feature of many signal transducing proteins and are key players in maintain P-homeostasis in plants. SPX domain containing proteins are subdivided into four groups. Group-I has proteins with exclusive SPX domain only and is further subdivided into three clades. Clade-I comprises of SPX1 and SPX2, clade-II consists of SPX3, SPX5, and SPX6 paralogous genes in rice of Arabidopsis SPX3 and clade III consists of SPX4 (Secco et al. 2012). As previously reported, SPX genes are involved in P-signaling and maintaining P-homeostasis in plants (Shi et al. 2014).

\section{INVOLVEMENT OF ETHYLENE BIOSYNTHESIS AND SIGNALING PATHWAY IN P-DEFICIENCY}

To determine effect of phosphorus starvation on ethylene hormone biosynthesis and signaling we analyzed expression of OsACO, OsACS1, OsCTR1, and OsEIN2. Transcript levels of ethylene biosynthesis genes OsACO, OsACS1 were increased significantly under low P concentration. Relative expression of OsEIN2 gene involved in ethylene signaling increased in phosphorous deficient root samples as compared with control, whereas OsCTR1 expression level decreased in phosphorous deficient plants (P0) as compared with control (Figure 6). As previously reported, ethylene signaling and biosynthesis both gets influenced by low P availability, ethylene production increases under different nutrient deficiencies (Mohd-Radzman et al. 2013). An increased ethylene production and signaling supported by up regulated expression of genes (OsACS1, OsACO, and OsEIN2) in both rice varieties (Fakhar-e-Malakand and 
Shadab). We conclude that by upregulating expression of OsACS1 and OsACO genes, plant produces more ethylene hormone, which in turn results in expression of ethylene response gene which also includes OsEIN2. Expression level of OsCTR1 decreased in low P concentrations. In presence of ethylene recepror-CTR1 (constitutive triple response 1) complex formation is inhibited due to ethylene binding with receptors which reduces transcript levels of CTR1 under phosphorous deficiency. Upregulation of ethylene plays significant role in imparting root architecture modifications which gets inhibited when inhibitor of ethylene such as AVG is applied (Patrick et al. 2009), ethylene has shown to be a central signaling molecule to mediate phosphorus starvation responses (Li et al. 2009). Here our results further validate that phosphorus starvation results in ethylene production and upregulation of ethylene signaling.

\section{INTERACTION OF CYTOKININ AND ETHYLENE PATHWAYS IN RESPONSE TO P-STARVATION}

Exogenously applied ACC and BAP positively regulate average root diameter and network area in $\mathrm{P}_{0}, \mathrm{ACC}$ alone slightly enhances network bushiness in $\mathrm{P}_{0}$ as well. On the other hand, ACC positively regulate root length in $\mathrm{P}_{\mathrm{N}}$ concentration whereas opposite effect is $\mathrm{P}_{0}$ seedlings was observed. Figure 7(a) shows scanned roots after fourteen days of growth at three varying P concentrations, different root parameters of Japonica rice variety measured at three different experimental treatments with GIA software (Figure 7(b)).

\section{EFFECT OF P-DEFICIENCY ON ROOT APICAL MERISTEM OF JAPONICA RICE VARIETY}

As previously described that $\mathrm{P}$ deficiency results in decrease in cell number at root apical meristem. Primary root tips of rice seedlings were microscopically analyzed to count cell number at RAM. As RAM is subdivided into three major zones i.e. stem cell niche, division zone and the zone of elongation. Cortex cells were counted to determine the RAM size starting from the quiescent center to the first elongated cell entering the elongation zone using microscopy of 14 days old rice seedlings, hydroponically grown rice seedlings of Japonica rice variety at following experimental conditions i.e. full phosphorus (PN), full phosphorus with $1 \mu \mathrm{M}$ ACC $\left(\mathrm{P}_{\mathrm{N}}+\mathrm{ACC}\right)$, full phosphorus with $1 \mu \mathrm{M}$ BAP $\left(\mathrm{P}_{\mathrm{N}}+\mathrm{BA}\right)$, zero phosphorus $\left(\mathrm{P}_{0}\right)$, zero phosphorus with $1 \mu \mathrm{MACC}\left(\mathrm{P}_{0}+\mathrm{ACC}\right)$ and zero phosphorus with $1 \mu \mathrm{M}$ BAP $\left(\mathrm{P}_{0}+\mathrm{BA}\right)$ shown in Figure 8(a). Similar to Pakistani varieties, Japonica rice variety's microscopic analysis showed significant decrease in cell number of root apical meristem at $\mathrm{P}_{0}$ as compared to $\mathrm{P}_{\mathrm{N}}$. ACC and BAP further negatively regulates RAM size at $\mathrm{P}_{\mathrm{N}}$ and $\mathrm{P}_{0}$ concentrations (Figure $8(\mathrm{~b})$ ). Both ethylene and cytokinin hormone induce RAM size shortening via crosstalk in between them involving two component signaling elements (Zdarska et al. 2019).

\section{EFFECT OF EXOGENOUSLY APPLIED CYTOKININ AND ETHYLENE PRECURSOR ON RELATIVE EXPRESSION OF P-TRANSPORTERS}

Relative expression of phosphorus transporters was measured in Japonica rice variety under full and zero phosphorus concentration with and without $1 \mu \mathrm{M}$ exogenously applied ACC and BAP. As we know that under phosphorus starvation, plants mostly upregulate phosphorus transporters to actively uptake phosphorus from the phosphorus deficient environment. ACC positively regulate expression of OsPT2 and OsPT4 at phosphorus starved conditions. ACC also positively regulates OsPT4 at full phosphorus concentration. As previously reported OsPT2 gene has ethylene responsive element which implicates that it's expression is regulated by ethylene hormone (Zhu et al. 2016). Our data further supports that ethylene hormone signaling is involved in expression of phosphorus transporters under P-deficient conditions to enhance P-uptake. Cytokinin as previously known to down regulate phosphorus mediated responses in plants here also strongly inhibit expression of OsPT2, OsPT4, and OsPT6 at zero phosphorus concentration. Similarly, exogenously applied cytokinin as BAP strongly down regulated basal level of OsPT4 at full phosphorus concentration. Figure 9 shows relative expression of phosphorus transporters (OsPT2, OsPT4, and OsPT6) of roots at full phosphorus $\left(\mathrm{P}_{\mathrm{N}}\right)$, full phosphorus with $1 \mu \mathrm{M}$ ACC $\left(\mathrm{P}_{\mathrm{N}}+\mathrm{ACC}\right)$, full phosphorus with $1 \mu \mathrm{M}$ BAP $\left(\mathrm{P}_{\mathrm{N}}\right.$ $+\mathrm{BA})$, zero phosphorus $\left(\mathrm{P}_{0}\right)$, zero phosphorus with $1 \mu \mathrm{M}$ ACC $\left(\mathrm{P}_{0}+\mathrm{ACC}\right)$ and zero phosphorus with $1 \mu \mathrm{M}$ BAP $\left(\mathrm{P}_{0}\right.$ $+\mathrm{BA})$. Cytokinin is known as the negative regulator of low phosphorus responses in plants. Application of exogenous cytokinin on P-starved plants causes the repression of genes induced in phosphorus starvation (Martín et al. 2008). Our results were concomitant with previously reported studies that cytokinin reverses the effect of phosphorus starvation at cellular and molecular level (Zeenat et al. 2018). Hence, we conclude that cytokinin negatively, whereas ethylene positively regulates phosphorus starvation effects. 
TABLE 1. List of genes and primers used for this study

\begin{tabular}{lrr}
\hline Gene ID & Forward primer sequence & Reverse primer sequence \\
\hline$\beta$-actin & GAAGATCACTGCCTTGCTCC & CGATAACAGCTCCTCTTGGC \\
OsACS1 & GAATTCGATGGTGAGCCAAGT & AGCGCGTGGGGGTTCTTC \\
OsACO & GTCCATGGAAACCAGGACCT & GAGCTCGTCGCGAGTAGTAA \\
OsEIN2 & CGGATAGGTACTATGATGGC & GCACTCGACACACCAAACAG \\
OsCTR1 & AGATCGCTTCAGGGAGTTTATG & ACAATAGGAGGGCTACGTTTATG \\
OsPT2 & CAGGCTAAGACGCAATG & GTGATGTCGGTGTAGTAAAG \\
OsPT4 & CACGGGTTACTGTTGATATT & GTAGGCGATGTTATTGTTATT \\
OsPT6 & CATCTTCACCAGCATCAA & AAGACGGTGAACCAGTA \\
\hline
\end{tabular}

TABLE 2. List of proteins predicted to interact with OsPT2, OsPT4 and OsPT6 via string network analysis

\begin{tabular}{|c|c|c|}
\hline Gene name & $\begin{array}{l}\text { Protein identifier in string } \\
\text { network }\end{array}$ & Function of network protein \\
\hline \multirow[t]{10}{*}{ OsPT2 } & & Low affinity phosphate transporter \\
\hline & OS06T0682900-01 (PSR) & Phosphosulfolactate synthase-related protein \\
\hline & OS01T0783000-01 & Putative uncharacterized protein \\
\hline & $\begin{array}{l}\text { OS06T0731800-01 } \\
\quad \text { (OsJ_22754) }\end{array}$ & Clathrin light chain 2 \\
\hline & OS06T0184900-01 (HCT3) & Putrescine hydroxycinnamoyltransferase 1 \\
\hline & OS01T0567600-00 (MST7) & $\begin{array}{l}\text { Sugar transport protein MST7; Mediates active uptake of hexoses by } \\
\text { sugar:proton symport }\end{array}$ \\
\hline & OS03T0406100-01 (SPX5) & Maintenance of cellular Pi homeostasis \\
\hline & OS03T0827500-01 (SPX4) & $\begin{array}{c}\text { Inositol polyphosphate sensor that associates with transcription factors to } \\
\text { negatively regulate Pi starvation }\end{array}$ \\
\hline & OS01T0897700-01, & annotation not available \\
\hline & OS07T0614700-01 (SPX6) & $\begin{array}{l}\text { Maintenance of cellular Pi homeostasis as a result of external fluctuation in } \\
\text { Pi levels }\end{array}$ \\
\hline
\end{tabular}


OS02T0593500-01

(OsJ_07345)

OsPT4

OS12T0180100-01

OS11T0186800-01

(OsJ 33231)

OS09T0570400-01

(OsJ_30419)

OS01T0279700-01

(P0003H10.9)

OS05T0451100-01

OS03T0406100-01 (SPX5)

OS09T0556400-01

OS10T0392600-01 (SPX3)

OS01T0852200-03

OS02T0593500-01

(OsJ_07345)

OsPT6

OS11T0109900-01 (DRB7)

OS01T0772000-01 (DRB1)

OS05T0380900-01(CML15)

OS01T0783000-01

OS05T0307400-01

Os01g0142300 (OsJ 00324)

Os07g0106000 (OsJ_22800)

OS05T0454500-01

(OsJ_18770)

Os02g0519800

OS04T0527000-01

(OsJ 15533)
Phosphate transporter

High affinity phosphate transporter

Probable anion transporter 7

Probable anion transporter 6

Probable anion transporter 4, chloroplastic

Probable anion transporter 1, chloroplastic

Probable anion transporter 2, chloroplastic

Maintenance of cellular Pi homeostasis as a result of external fluctuation in Pi levels, works in coordination with SPX3

Probable anion transporter 5, chloroplastic

Maintenance of cellular Pi homeostasis as a result of external fluctuation in Pi levels

Probable anion transporter 3, chloroplastic

Phosphate transporter

High-affinity phosphate transporter

Double-stranded RNA-binding protein 7

Double-stranded RNA-binding protein 1

Potential calcium sensor

Putative uncharacterized protein

Double-stranded RNA-binding protein 3

Putative uncharacterized protein

Putative uncharacterized protein

Putative uncharacterized protein

Putative uncharacterized protein

Putative uncharacterized protein 


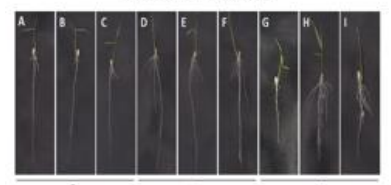

Muskaan

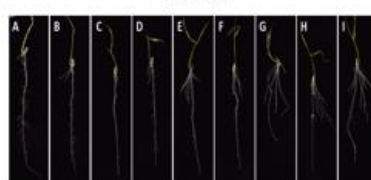

Super Basmati

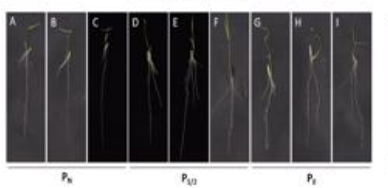

IR6

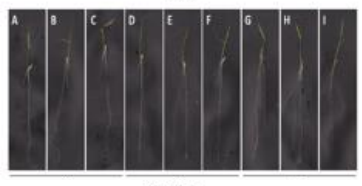

Shadab

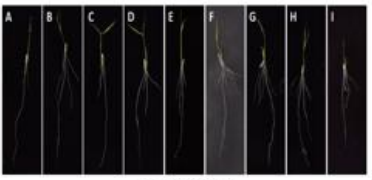

Super Kernel

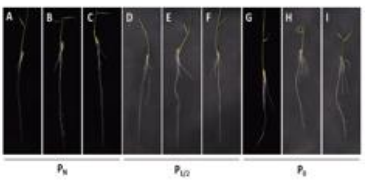

$\mathrm{b}$
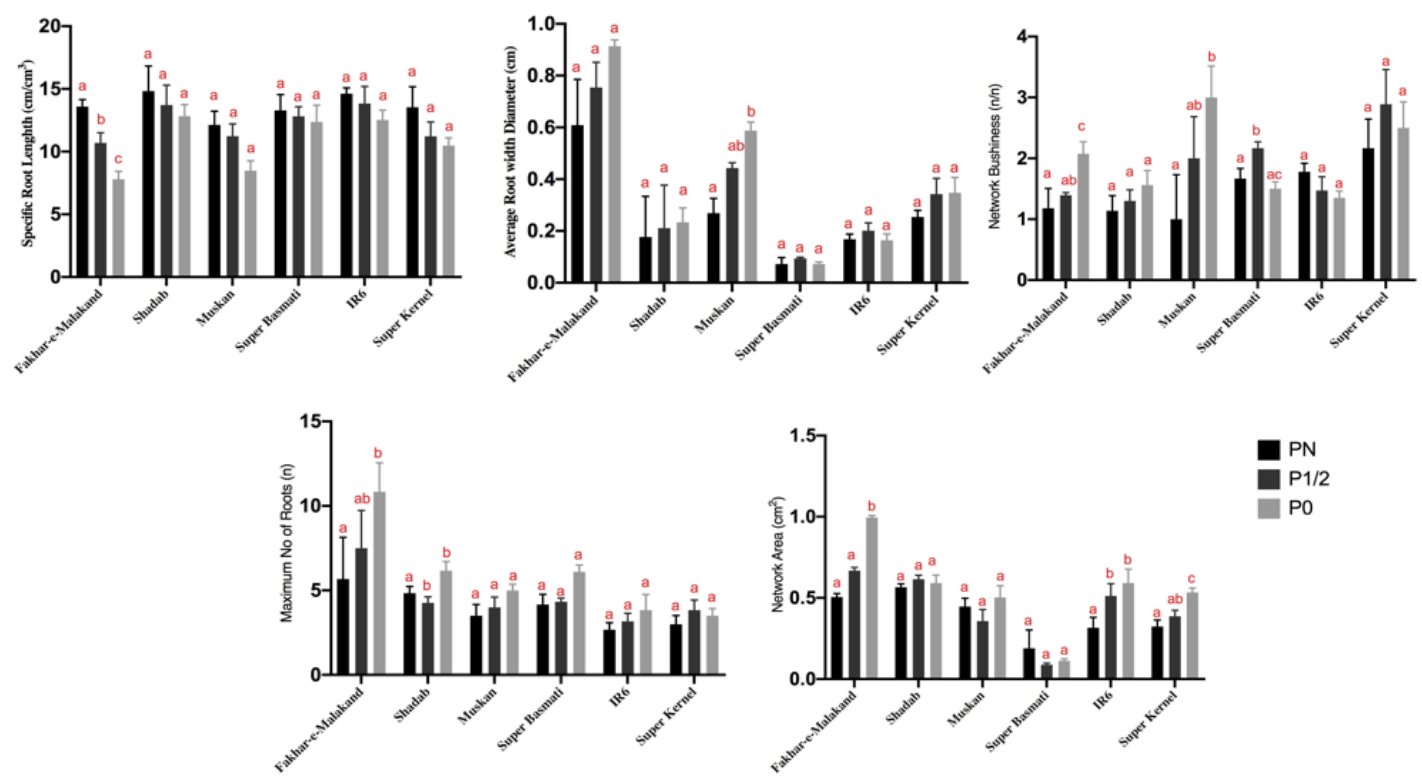

ㅁ
P1/2
P0

FIGURE 1. Rice root architecture modification in response to phosphorus starvation

a) Scanned images of selected rice varieties grown in $\operatorname{Normal}\left(\mathrm{P}_{\mathrm{N}}\right)$, phosphorus deficient $\left(\mathrm{P}_{1 / 2}\right)$ and Phosphorus starved $\left(\mathrm{P}_{0}\right)$ conditions after 14 days of growth. (A-C) Represent rice seedlings grown on normal phosphorous concentration $\left(\mathrm{P}_{\mathrm{N}}\right)$, (D-F) Represent rice seedlings grown on half phosphorus concentration $\left(\mathrm{P}_{1 / 2}\right)$ and $(\mathrm{G}-\mathrm{I})$ Represent rice seedlings grown showing plants grown on phosphorous starved conditions. b) Different root parameters were analyzed to check overall effects at varying phosphorus concentrations i.e. Specific root length, Average root width diameter, Maximum number of roots, Network bushiness and Network area was analyzed to study effect of phosphorus on root architecture of commonly grown rice varieties. For comparison within each variety at three different experimental conditions i.e. $\mathrm{P}_{\mathrm{N}}, \mathrm{P}_{1 / 2}$ and $\mathrm{P}_{0}$; oneway ANOVA with post hoc Holm multiple- comparison calculated; $n=3$ at $\mathrm{p}<0.05$. Fakhar-e-Malakand showed significant decrease in specific root length at $\mathrm{P}_{0}$ whereas significant increase was observed in network bushiness, maximum number of roots and network area of Fakhar-e-Malakand as compared to other varieties 

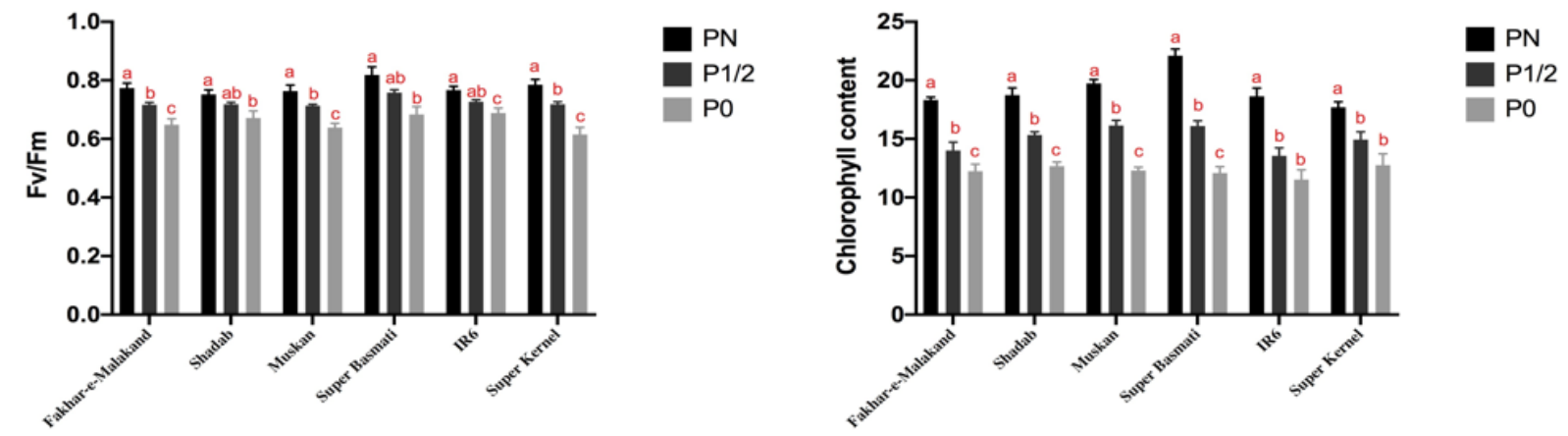

FIGURE 2. Significant decrease in photosynthetic activity of rice seedlings due to phosphorus starvation. Fv/Fm ratio and chlorophyll content of six rice varieties (Fakhar-e-Malakand, Muskan, Super Kernel, Super Basmati, IR6 and Shadab) were measured at varying P concentration for analyzing impact of P-starvation. For comparison within each variety at three different experimental conditions i.e. $\mathrm{P}_{\mathrm{N}}, \mathrm{P}_{1 / 2}$ and $\mathrm{P}_{0}$; one-way ANOVA, with post hoc Holm multiple- comparison calculated; $n=3$ at $p<0.05$. All varieties showed significant decrease in chlorophyll content and $\mathrm{Fv} / \mathrm{Fm}$ ration corresponding photosynthetic activity under $\mathrm{P}_{0}$ condition

a
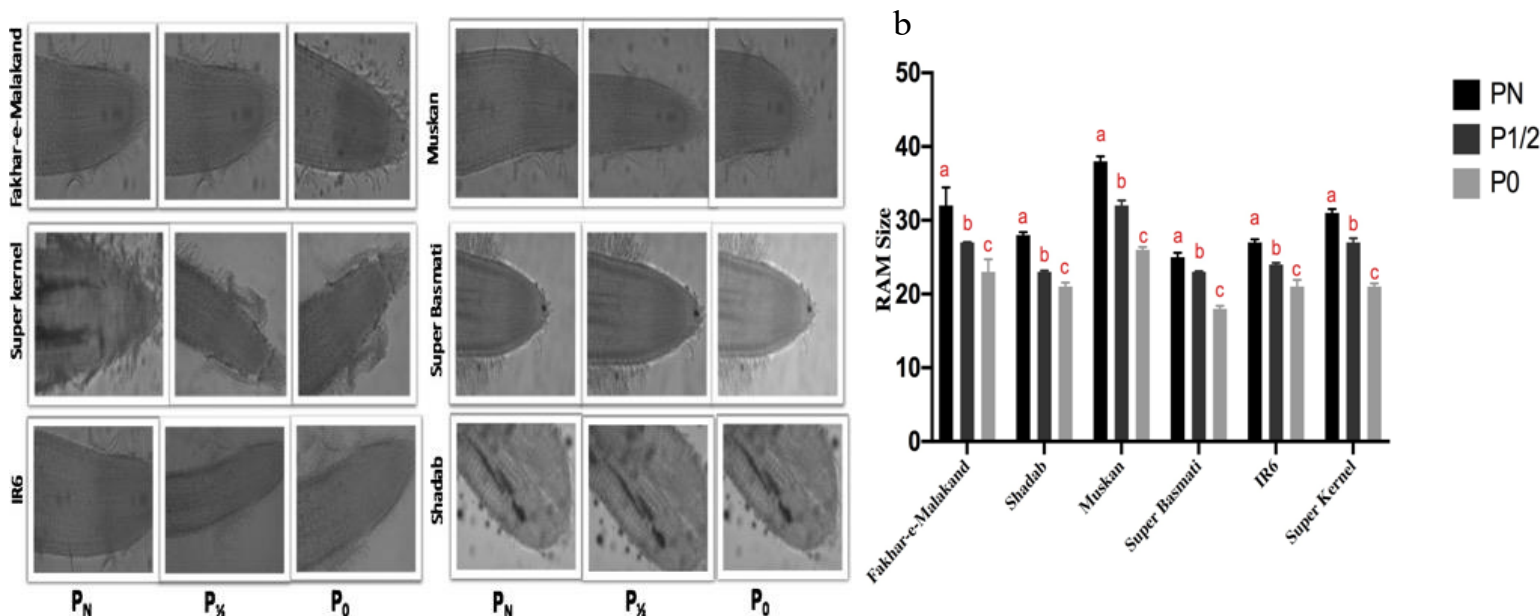

FIGURE 3. Reduction in root apical meristematic zone of rice seedlings due to phosphorus starvation. a) Microscopic images of root tips from each treatment of all verities were obtained by chloral hydrate method. Nikon Eclipse 90i optical microscope was used to get microscopic images for cell count. b) Bar graph showing cell count in 14 days old seedlings of rice varieties grown under different phosphorous conditions. The means $(n=3)$ shown here. Results are presented in mean \pm SEM. Error bars. For comparison within each variety at three different experimental conditions i.e. $\mathrm{P}_{\mathrm{N}}, \mathrm{P}_{1 / 2}$ and $\mathrm{P}_{0}$; one-way ANOVA with post hoc Holm multiple- comparison calculated; $n=3$ at $p<0.05$. Significant decrease in RAM size of all varieties was observed at $\mathrm{P}_{0}$ condition 

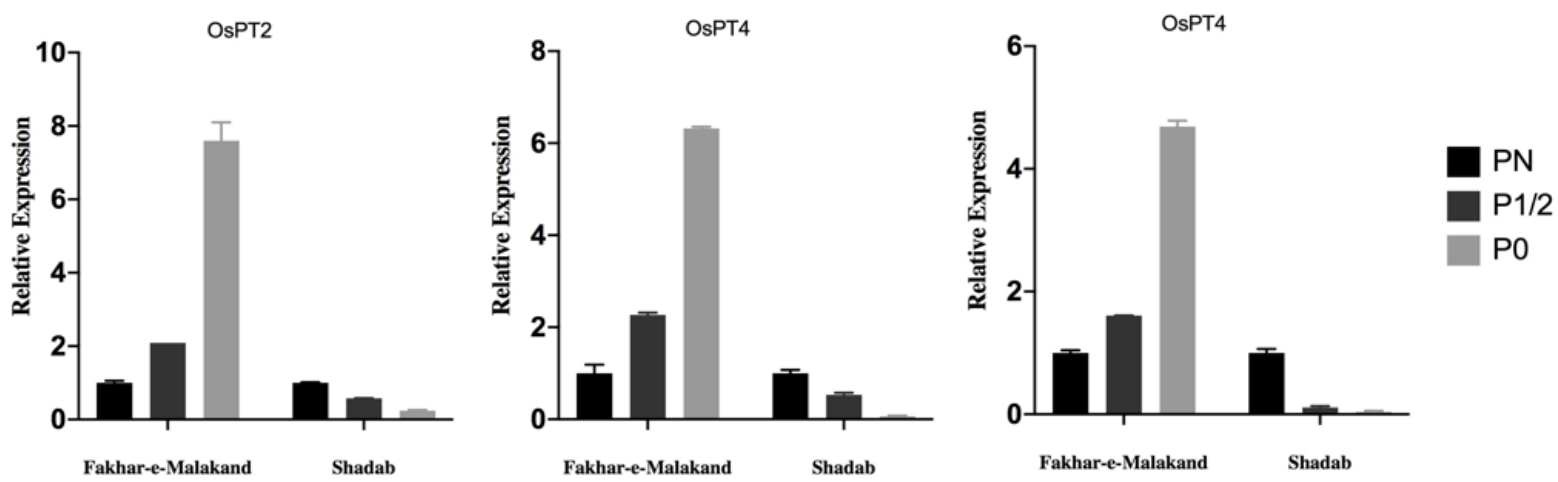

FIGURE 4. Variety specific response in expression of phosphorus transporters due to P-starvation. P-deficiency induces expression of OsPT2, OsPT4, and OsPT6 genes in Fakhar-e-Malakand variety, whereas in Shadab variety gene expression levels of OsPT2, OsPT4, and OsPT6 were reduced in response to low phosphorus levels. $\beta$ - actin was used for normalization of target genes. Results are presented in mean \pm SEM

a

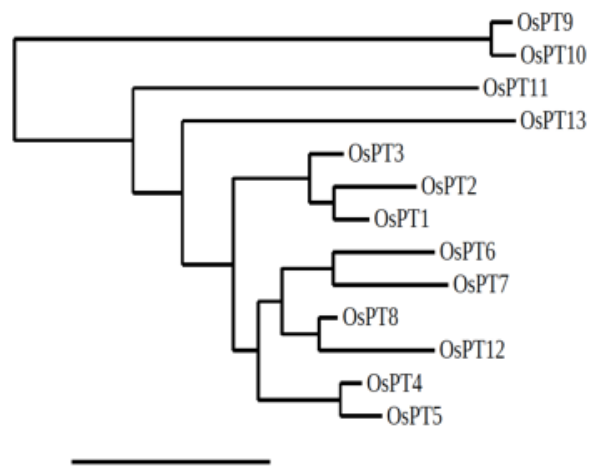

0.2 $\mathrm{b}$
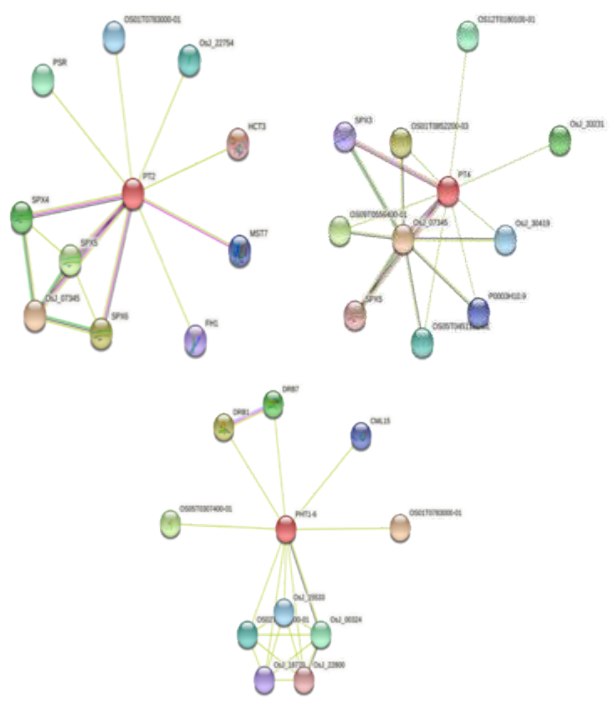

FIGURE 5. a) Phylogenetic tree of selected phosphorus transporters of rice. Protein sequences were retrieved from NCBI database, phylogenetic tree was constructed using online tool (https://www.phylogeny.fr/). b) String network of OsPT2, OsPT4 and OsPT6 was constructed. Protein-protein association was graphed by giving protein sequence of respective transporters 

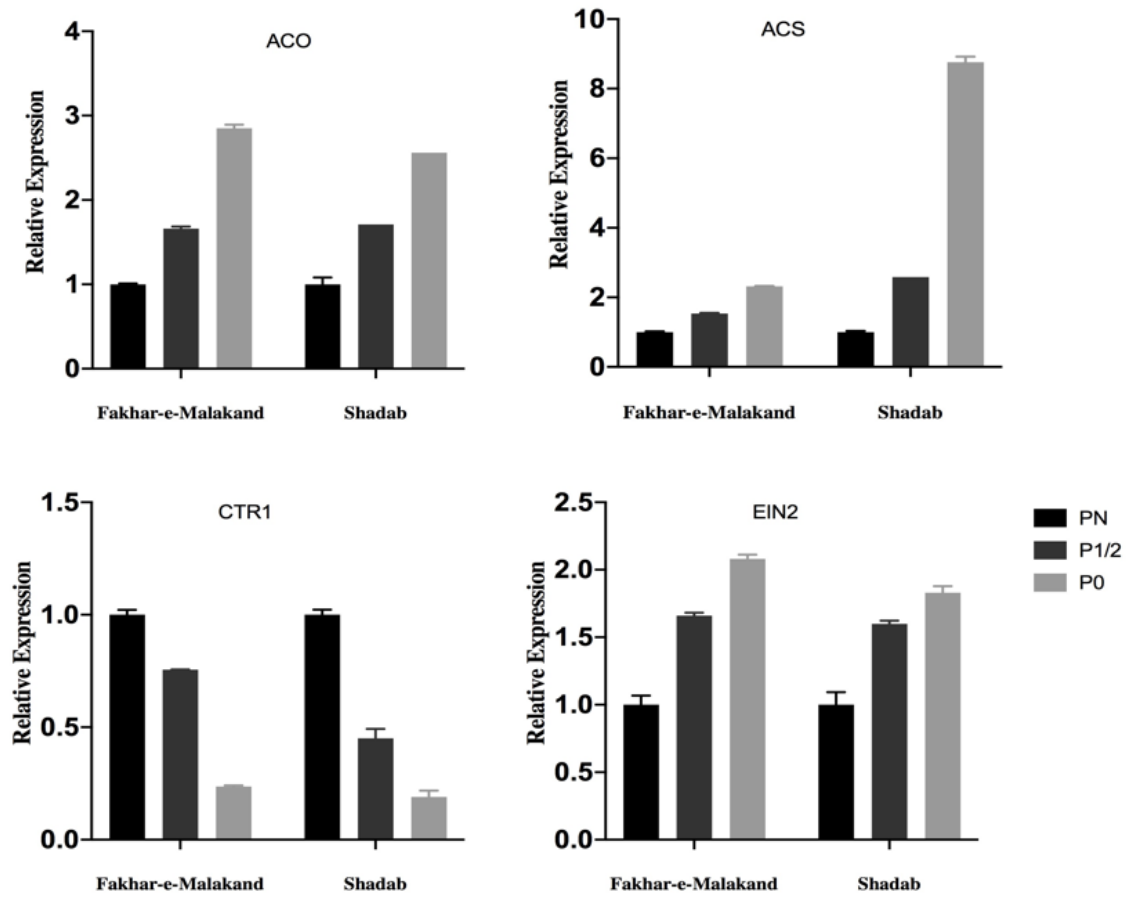

FIGURE 6. Phosphorus starvation mediated up-regulation of ethylene biosynthesis and signaling genes in roots of rice seedlings grown at three different experimental conditions i.e. $\mathrm{P}_{\mathrm{N}}, \mathrm{P}_{1 / 2}$ and $\mathrm{P}_{0}$. P-deficiency induced OsACO, OsACS1, and OsEIN2 gene expression in both varieties under phosphorous deficiency while OsCTR1 expression was decreased. $\beta$ - actin was used for normalization of target genes. Results are presented as mean $(n=3)$. Error bars are $\pm S E$
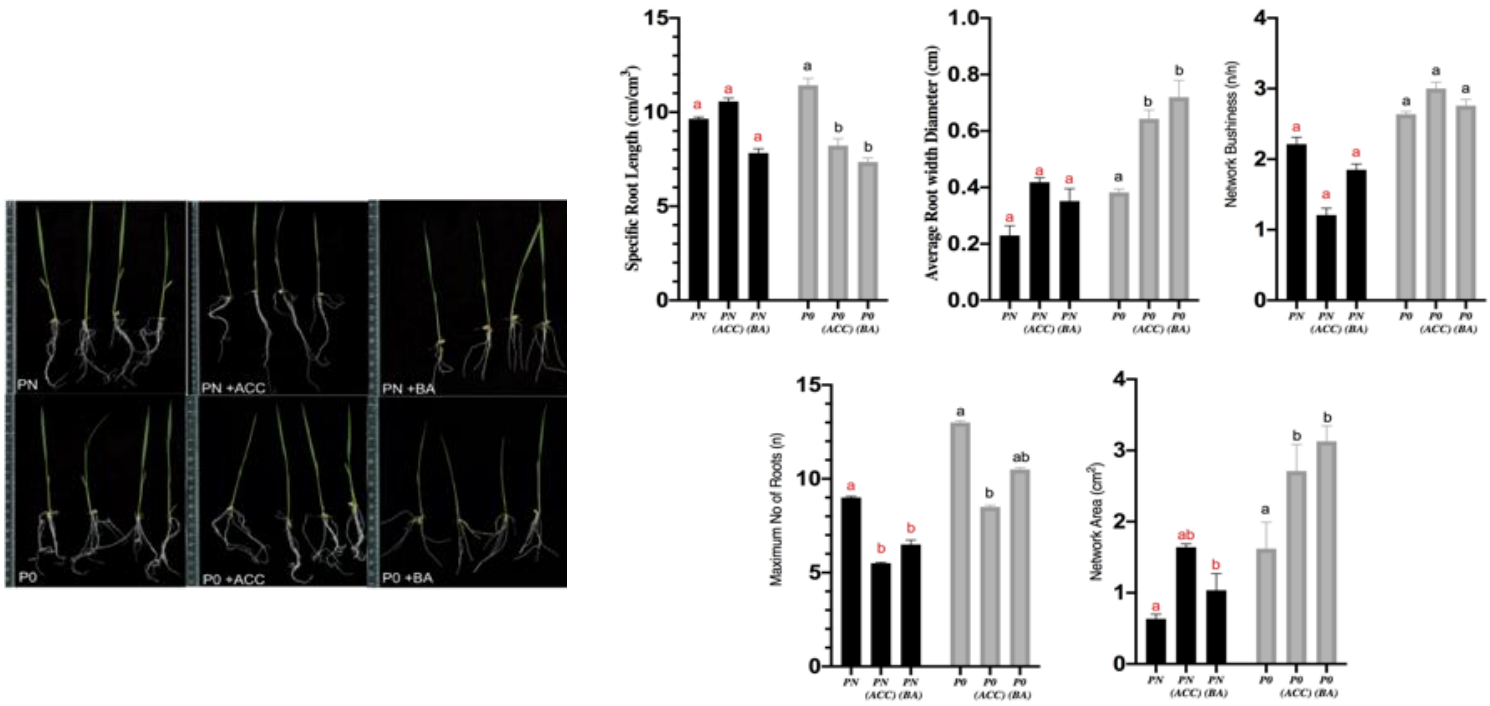

FIGURE 7. Effect of exogenously applied ACC and BA on Phosphorus starved Japonica rice variety. Four representative seedlings from each treatment i.e. $\mathrm{PN}, \mathrm{PN}+\mathrm{ACC}, \mathrm{PN}+\mathrm{BA}, \mathrm{P}_{0}, \mathrm{P}_{0}+\mathrm{ACC}$ and $\mathrm{P}_{0}+\mathrm{BA}$ were scanned via GIA software to measure specific root length, average root width diameter, maximum number of roots, network bushiness and network area. One-way ANOVA was applied to compare $\mathrm{P}_{\mathrm{N}}, \mathrm{P}_{\mathrm{N}}+\mathrm{ACC}$ and $\mathrm{P}_{\mathrm{N}}+\mathrm{BA}$ at $\mathrm{p}<0.05$, showed with red alphabets similarly, to show significance within $\mathrm{P}_{0}$ vs all treatments i.e. $\mathrm{P}_{0}+\mathrm{BA}$ and $\mathrm{P}_{0}+\mathrm{ACC}$ was shown by dark blue alphabets 
$\mathrm{a}$

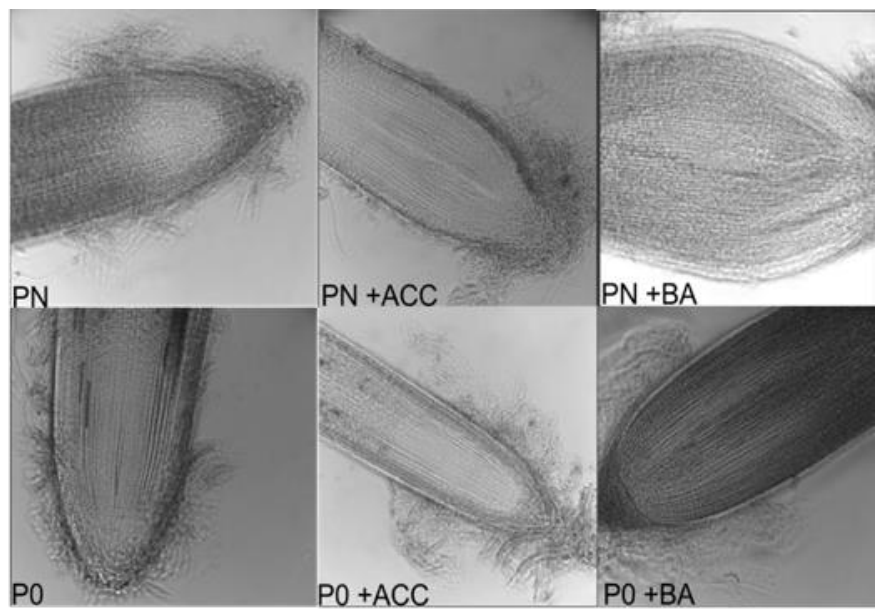

b

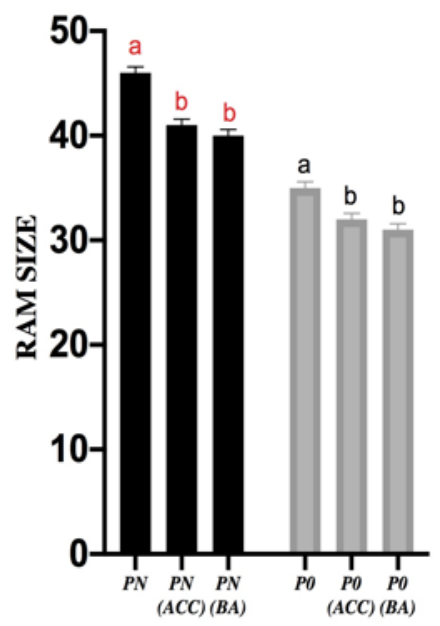

FIGURE 8. Exogenous ethylene and cytokinin hormone negatively regulate root apical meristem zone in rice, similar to P-starvation response. a) Microscopic images of root tips from each treatment was obtained by chloral hydrate method. Nikon Eclipse 90i optical microscope was used to get microscopic images for cell count.

b) Graphical representation of number of cells at RAM of rice seedlings grown hydroponically at following experimental conditions i.e. $\mathrm{P}_{\mathrm{N}}, \mathrm{P}_{\mathrm{N}}+\mathrm{ACC}, \mathrm{P}_{\mathrm{N}}+\mathrm{BA}, \mathrm{P}_{0}, \mathrm{P}_{0}+\mathrm{ACC}$ and $\mathrm{P}_{0}+\mathrm{BA}$. One-way ANOVA was applied to compare $\mathrm{P}_{\mathrm{N}}, \mathrm{P}_{\mathrm{N}}+\mathrm{ACC}$ and $\mathrm{P}_{\mathrm{N}}+\mathrm{BA}$ at $\mathrm{p}<0.05$, showed with red alphabets similarly, to show significance within $\mathrm{P}_{0}$ vs all treatment dark blue alphabets were used
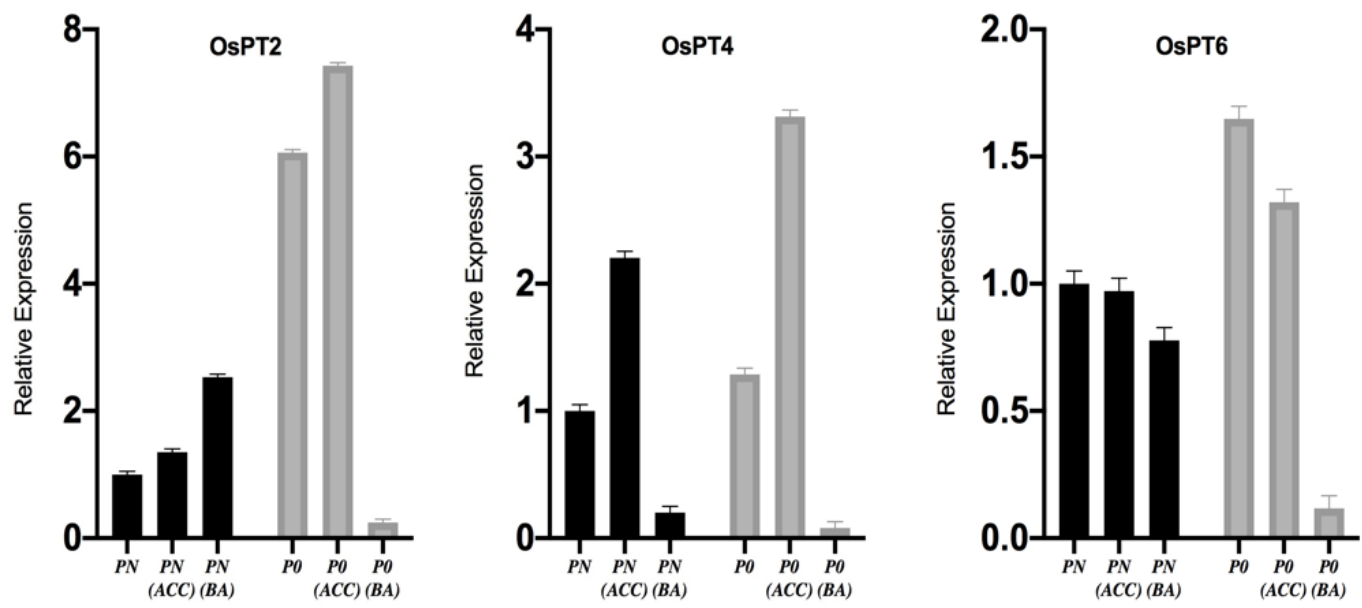

FIGURE 9. Relative expression of phosphorus transporters (OsPT2, OsPT4 and OsPT6) in roots of Japonica rice variety. Ethylene (ACC) positively regulates expression of OsPT2 and OsPT4 at zero phosphorus whereas at normal concentration it increases expression of OsPT4 by one-fold. Cytokinin (BA) on the other hand strongly down regulates expression of all three transporters (OsPT2, OsPT4 and OsPT6) at zero phosphorus concentration. $\beta$ - actin was used for normalization of target genes. Results are presented in mean \pm SEM. Error bars 


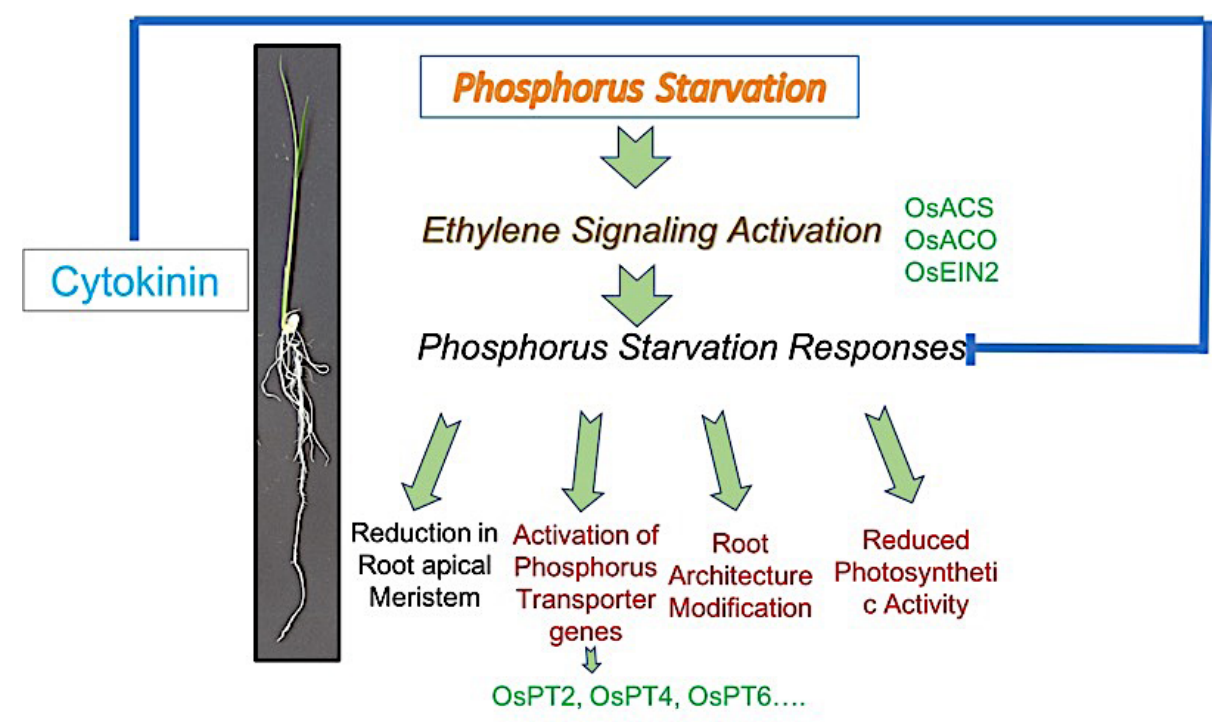

FIGURE 10. Model illustrating role of Ethylene and Cytokinin hormone during P starvation. Ethylene hormone signaling is activated in response to phosphorus stress which consequently results in mediating phosphorus starvation responses. Cytokinin inhibits phosphorus starvation responses shown in red

\section{CONCLUSION}

Phosphorous deficiency regulates root architecture modifications which varies between different species even in between varieties of same species. In current study, we present a simple method to identify best adapted variety on basis of root architecture modification which correlates with phosphorus transporter production, thereby indicates that variety with efficient root modification has upregulation of phosphorus transporters to enhance phosphorus acquisition. Based on our findings from the current study, we summarized the role of ethylene and cytokinin hormone during P starvation and proposed a model (Figure 10). Moreover, a detail study on interaction of phosphorus starvation responses and phytohormones like cytokinin and ethylene will help to reveal underlying cross talk that can further help to isolate better adapted plant species/varieties under phosphorus starved conditions.

\section{ACKNOWLEDGEMENTS}

This project was funded by Quaid-i-Azam University, Pakistan.

\section{REFERENCES}

Abbas, M., Irfan, M., Shah, J. \& Memon, M. 2018. Intra-specific variations among wheat genotypes for phosphorus use efficiency. Asian Journal of Agriculture and Biology 6(1): 35-45.

Ai, P., Sun, S., Zhao, J., Fan, X., Xin, W., Guo, Q., Yu, L., Shen, Q., Wu, P., Miller, A.J. \& Xu, G. 2009. Two rice phosphate transporters, OsPht1;2 and OsPht 1;6, have different functions and kinetic properties in uptake and translocation. The Plant Journal: For Cell and Molecular Biology 57(5): 798-809.

Akhtar, M.S., Oki, Y., Nakashima, Y., Adachi, T. \& Nishigaki, M. 2016. Phosphorus stress-induced differential growth, and phosphorus acquisition and use efficiency by spring wheat cultivars. Communications in Soil Science and Plant Analysis 47(sup1): 15-27.

Aziz, N.I.H.A. \& Hanafiah, M.M. 2020. Life cycle analysis of biogas production from anaerobic digestion of palm oil mill effluent. Renewable Energy 145: 847-857.

Aziz, T., Finnegan, P.M., Lambers, H. \& Jost, R. 2014. Organspecific phosphorus-allocation patterns and transcript profiles linked to phosphorus efficiency in two contrasting wheat genotypes. Plant, Cell and Environment 37(4): 943960 . 
Campos, P., Borie, F., Cornejo, P., López-Ráez, J.A., LópezGarcía, Á. \& Seguel, A. 2018. Phosphorus acquisition efficiency related to root traits: Is mycorrhizal symbiosis a key factor to wheat and barley cropping? Frontiers in Plant Science 9: 752.

Carstensen, A., Herdean, A., Schmidt, S.B., Sharma, A., Spetea, C., Pribil, M. \& Husted, S. 2018. The impacts of phosphorus deficiency on the photosynthetic electron transport chain. Plant Physiology 177(1): 271-284.

Che Mat, N., Bhuiyan, M., Senan, S., Yaakob, Z. \& Wickneswari, R. 2015. Selection of high yielding Jatropha curcas L. accessions for elite hybrid seed production. Sains Malaysiana 44(11): 1567-1572.

Chithrameenal, K., Alagarasan, G., Raveendran, M., Robin, S., Meena, S., Ramanathan, A. \& Ramalingam, J. 2018. Genetic enhancement of phosphorus starvation tolerance through marker assisted introgression of OsPSTOL1 gene in rice genotypes harbouring bacterial blight and blast resistance. PLoS ONE 13(9): 0204144.

Dai, X., Wang, Y., Yang, A. \& Zhang, W.H. 2012. OsMYB2P-1, an R2R3 MYB transcription factor, is involved in the regulation of phosphate-starvation responses and root architecture in rice. Plant Physiology 159(1): 169-183.

Elser, J.J. 2012. Phosphorus: A limiting nutrient for humanity? Current Opinion in Biotechnology 23(6): 833-838.

Fageria, N.K., Santos, A.B. \& Heinemann, A.B. 2011. Lowland rice genotypes evaluation for phosphorus use efficiency in tropical lowland. Journal of Plant Nutrition 34(8): 1087-1095.

Fahad, S., Hussain, S., Bano, A., Saud, S., Hassan, S., Shan, D., Khan, F.A., Khan, F., Chen, Y., Wu, C., Tabassum, M.A., Chun, M.X., Afzal, M., Jan, A., Jan, M.T. \& Huang, J. 2015. Potential role of phytohormones and plant growthpromoting rhizobacteria in abiotic stresses: Consequences for changing environment. Environmental Science and Pollution Research International 22(7): 4907-4921.

Galkovskyi, T., Mileyko, Y., Bucksch, A., Moore, B., Symonova, O., Price, C.A., Topp, C.N., Iyer-Pascuzzi, A.S., Zurek, P.R., Fang, S., Harer, J., Benfey, P.N. \& Weitz, J.S. 2012. GiA roots: Software for the high throughput analysis of plant root system architecture. BMC Plant Biology 12: 116.

Goff, S.A., Ricke, D., Lan, T.H., Presting, G., Wang, R., Dunn, M., Glazebrook, J., Sessions, A., Oeller, P., Varma, H., Hadley, D., Hutchison, D., Martin, C., Katagiri, F., Markus Lange, B., Moughamer, T., Xia, Y., Budworth, P., Zhong, J., Miguel, T., Paszkowski, U., Zhang, S., Colbert, M., Sun, W.L., Chen, L., Cooper, B., Park, S., Wood, T.C., Mao, L., Quail, P., Wing, R., Dean, R., Yu, Y., Zharkikh, A., Shen, R., Sahasrabudhe, S., Thomas, A., Cannings, R., Gutin, A., Pruss, D., Reid, J., Tavtigian, S., Mitchell, J., Eldredge, G., Scholl, T., Miller, R.M., Bhatnagar, S., Adey, N., Rubano, T., Tusneem, N., Robinson, R., Feldhaus, J., Macalma, T., Oliphant, A. \& Briggs, S. 2002. A draft sequence of the rice genome (Oryza sativa L. ssp. aponica). Science 296(5565): 92-100.
Gu, M., Chen, A., Sun, S. \& Xu, G. 2016. Complex regulation of plant phosphate transporters and the gap between molecular mechanisms and practical application: What is missing? Molecular Plant 9(3): 396-416.

Harun, S.N., Hanafiah, M.M. \& Abd. Aziz, N.I.H. 2020. An LCA-based environmental performance of rice production for developing a sustainable agri-food system in Malaysia. Environmental Management 67(2): 146-161.

Hassan, M., Hanafiah, M., Taha, Z. \& Hadi, I. 2020. Effect of low-intensity laser irradiation on field performance of maize (Zea mays L.) emergence, phenological and seed quality characteristics. Applied Ecology and Environmental Research 18(4): 6009-6023.

Hasan, Md.M., Hasan, Md.M., Teixeira da Silva, J.A. \& Li, X. 2016. Regulation of phosphorus uptake and utilization: Transitioning from current knowledge to practical strategies. Cellular and Molecular Biology Letters 21(7): 1-19.

Irfan, M., Shah, J.A. \& Abbas, M. 2017. Evaluating the performance of mungbean genotypes for grain yield, phosphorus accumulation and utilization efficiency. Journal of Plant Nutrition 40(19): 2709-2720.

Jackson, M.B. 2008. Ethylene-promoted elongation: An adaptation to submergence stress. Annals of Botany 101(2): 229-248.

Kang, J., Yu, H., Tian, C., Zhou, W., Li, C., Jiao, Y. \& Liu, D. 2014. Suppression of photosynthetic gene expression in roots is required for sustained root growth under phosphate deficiency. Plant Physiology 165(3): 1156-1170.

Karthikeyan, A.S. 2002. Regulated expression of arabidopsis phosphate transporters. Plant Physiology 130(1): 221-233.

Kim, H.J., Lynch, J.P. \& Brown, K.M. 2008. Ethylene insensitivity impedes a subset of responses to phosphorus deficiency in tomato and petunia. Plant, Cell and Environment 31(12): 1744-1755.

Li, Y.S., Mao, X.T., Tian, Q., Li, L.H. \& Zhang, W.H. 2009. Phosphorus deficiency-induced reduction in root hydraulic conductivity in Medicago falcata is associated with ethylene production. Environ. Exp. Bot. 67(1): 172-177.

Liu, F., Wang, Z., Ren, H., Shen, C., Li, Y., Ling, H.Q., Wu, C., Lian, X. \& Wu, P. 2010. OsSPX1 suppresses the function of OsPHR2 in the regulation of expression of OsPT2 and phosphate homeostasis in shoots of rice. The Plant Journal: For Cell and Molecular Biology 62(3): 508-517.

Liu, T.Y., Huang, T.K., Yang, S.Y., Hong, Y.T., Huang, S.M., Wang, F.N., Chiang, S.F., Tsai, S.Y., Lu, W.C. \& Chiou, T.J. 2016. Identification of plant vacuolar transporters mediating phosphate storage. Nature Communications 7: 11095.

Lobell, D.B. \& Gourdji, S.M. 2012. The influence of climate change on global crop productivity. Plant Physiology 160(4): 1686-1697.

López-Arredondo, D.L., Leyva-González, M.A., GonzálezMorales, S.I., López-Bucio, J. \& Herrera-Estrella, L. 2014. Phosphate nutrition: Improving low-phosphate tolerance in crops. Annual Review of Plant Biology 65: 95-123. 
Ma, Z., Baskin, T.I., Brown, K.M. \& Lynch, J.P. 2003. Regulation of root elongation under phosphorus stress involves changes in ethylene responsiveness. Plant Physiology 131(3): 13811390.

Martín, A.C., Pozo, J.C.D., Iglesias, J., Rubio, V., Solano, R., Peña, A.D.L., Leyva, A. \& Paz-Ares, J. 2008. Influence of cytokinins on the expression of phosphate starvation responsive genes in Arabidopsis. The Plant Journal 24(5): 559-567.

Młodzińska, E. \& Zboińska, M. 2016. Phosphate uptake and allocation - A closer look at Arabidopsis thaliana L. and Oryza sativa L. Frontiers in Plant Science 7: 1198.

Mohd-Radzman, N.A., Djordjevic, M.A. \& Imin, N. 2013. Nitrogen modulation of legume root architecture signaling pathways involves phytohormones and small regulatory molecules. Frontiers in Plant Science 4: 385.

Muthayya, S., Sugimoto, J.D., Montgomery, S. \& Maberly, G.F. 2014. An overview of global rice production, supply, trade, and consumption. Annals of the New York Academy of Sciences 1324: 7-14.

Nadira, U.A., Ahmed, I.M., Wu, F. \& Zhang, G. 2016. The regulation of root growth in response to phosphorus deficiency mediated by phytohormones in a Tibetan wild barley accession. Acta Physiologiae Plantarum 38(4): 105.

Patrick, B., Antonin, L., Servane, L.L., Deleu, C. \& Deunff, E.L. 2009. Ethylene modifies architecture of root system in response to stomatal opening and water allocation changes between root and shoot. Plant Signaling and Behavior 4(1): 44-46.

Péret, B., Desnos, T., Jost, R., Kanno, S., Berkowitz, O. \& Nussaume, L. 2014. Root architecture responses: In search of phosphate. Plant Physiology 166(4): 1713-1723.

Perilli, S. \& Sabatini, S. 2010. Methods in Molecular Biology: Analysis of Root Meristem Size Development. New Jersey: Humana Press.

Plaxton, W.C. \& Tran, H.T. 2011. Metabolic adaptations of phosphate-starved plants. Plant Physiology 156(3): 10061015

Poirier, Y. \& Bucher, M. 2004. Phosphate transport and homeostasis in arabidopsis. The Arabidopsis Book 1: e0024.

Rafii, M., Zakiah, M.Z., Asfaliza, R., Iffah Haifaa, M.D., Latif, M.A. \& Malek, M.A. 2014. Grain quality performance and heritability estimation in selected F-1 rice genotypes. Sains Malaysiana 43(1): 1-7.

Raghothama, K.G. 2000. Phosphate transport and signaling. Current Opinion in Plant Biology 3(3): 182-187.

Secco, D., Wang, C., Arpat, B.A., Wang, Z., Poirier, Y., Tyerman, S.D., Wu, P., Shou, H. \& Whelan, J. 2012. The emerging importance of the SPX domain-containing proteins in phosphate homeostasis. The New Phytologist 193(4): 842851.

Shi, J., Hu, H., Zhang, K., Zhang, W., Yu, Y., Wu, Z. \& Wu, P. 2014. The paralogous SPX3 and SPX5 genes redundantly modulate Pi homeostasis in rice. Journal of Experimental Botany 65(3): 859-870.
Smith, F.A., Jakobsen, I. \& Smith, S.E. 2000. Spatial differences in acquisition of soil phosphate between two arbuscular mycorrhizal fungi in symbiosis with Medicago truncatula. New Phytologist 147(2): 357-366.

Song, L. \& Liu, D. 2015. Ethylene and plant responses to phosphate deficiency. Frontiers in Plant Science 6: 796.

Stepanova, A.N. \& Alonso, J.M. 2009. Ethylene signaling and response: Where different regulatory modules meet. Current Opinion in Plant Biology 12(5): 548-555.

Svistoonoff, S., Creff, A., Reymond, M., Sigoillot-Claude, C., Ricaud, L., Blanchet, A., Nussaume, L. \& Desnos, T. 2007. Root tip contact with low-phosphate media reprograms plant root architecture. Nature Genetics 39(6): 792-796.

Swarup, R., Perry, P., Hagenbeek, D., Van Der Straeten, D., Beemster, G.T.S., Sandberg, G., Bhalerao, R., Ljung, K. \& Bennett, M.J. 2007. Ethylene upregulates auxin biosynthesis in arabidopsis seedlings to enhance inhibition of root cell elongation. The Plant Cell 19(7): 2186-2196.

Teng, W., Zhao, Y.Y., Zhao, X.Q., He, X., Ma, W.Y., Deng, Y., Chen, X.P. \& Tong, Y.P. 2017. Genome-wide identification, characterization, and expression analysis of PHT1 phosphate transporters in wheat. Frontiers in Plant Science 8: 543

Voß, U., Bishopp, A., Farcot, E. \& Bennett, M.J. 2014. Modelling hormonal response and development. Trends in Plant Science 19(5): 311-319.

White, P.J., George, T.S., Gregory, P.J., Bengough, A.G., Hallett, P.D. \& McKenzie, B.M. 2013. Matching roots to their environment. Annals of Botany 112(2): 207-222.

Xu, H.X., Weng, X.Y. \& Yang, Y. 2007. Effect of phosphorus deficiency on the photosynthetic characteristics of rice plants. Russian Journal of Plant Physiology 54(6): 741-748.

Zdarska, M., Cuyacot, A.R., Tarr, P.T., Yamoune, A., Szmitkowska, A., Hrdinová, V., Gelová, Z., Meyerowitz, E.M. \& Hejátko, J. 2019. ETR1 integrates response to ethylene and cytokinins into a single multistep phosphorelay pathway to control root growth. Molecular Plant 12(10): $1338-1352$.

Zeenat, A., Zulfiqar, A., Ramzan, A., Heckathorn, S.A. \& Shakeel, S.N. 2018. Cytokinin interaction to cope with phosphorous starvation in rice. International Journal of Agriculture and Biology 20(11): 2446-2454.

Zhang, F., Sun, Y., Pei, W., Jain, A., Sun, R., Cao, Y., Wu, X., Jiang, T., Zhang, L., Fan, X., Chen, A., Shen, Q., Xu, G. \& Sun, S. 2015. Involvement of OsPht1;4 in phosphate acquisition and mobilization facilitates embryo development in rice. The Plant Journal 82(4): 556-569.

Zhang, Z., Liao, H. \& Lucas, W.J. 2014. Molecular mechanisms underlying phosphate sensing, signaling, and adaptation in plants. Journal of Integrative Plant Biology 56(3): 192-220.

Zhu, X.F., Zhu, C.Q., Zhao, X.S., Zheng, S.J. \& Shen, R.F. 2016. Ethylene is involved in root phosphorus remobilization in rice (Oryza sativa) by regulating cell-wall pectin and enhancing phosphate translocation to shoots. Annals of Botany 118(4): 645-653. 
Alveena Zulfiqar, Beenish Jehan Azhar, Aroosa Zeb, Asyia Zeenat, Sitwat Aman \& Samina N Shakeel*

Department of Biochemistry

Quaid-i-Azam University

Islamabad

Pakistan

\section{Scott A Heckerthorn}

Department of Environmental Sciences

University of Toledo

Toledo

Ohio 43606

USA
Samina N Shakeel*

Department of Biological Sciences

Dartmouth College

Hanover, NH

USA

*Corresponding author; email: snq28@yahoo.com

Received: 13 November 2019

Accepted: 6 November 2020 